\title{
LOWER DEVONIAN STROMATOPOROIDS FROM THE NORTHERN OBEJO-VALSEQUILLO-PUEBLA DE LA REINA DOMAIN (BADAJOZ AND CÓRDOBA PROVINCES, SOUTHERN SPAIN)
}

\author{
Andreas MAY \\ Saint Louis University - Madrid campus, Avda. del Valle, 34, E-28003 Madrid, \\ Spain. Email: maya@madrid.slu.edu
}

May, A. 2006. Lower Devonian Stromatoporoids from the northern Obejo-Valsequillo-Puebla de la Reina Domain (Badajoz and Córdoba Provinces, Southern Spain).[ Estromatoporoideos del Devónico Inferior de la parte norte del Dominio Obejo-Valsequillo-Puebla de la Reina (provincias de Badajoz y Córdoba, Sur de España).] Revista Española de Paleontología, 21 (1), 29-38, ISSN 0213-6937

\begin{abstract}
The stromatoporoid fauna from three locations in the "Peñón Cortado Limestone" (Pragian to Upper Emsian) from the area of Quintana de la Serena (Badajoz Province) and Peñarroya-Pueblonuevo (Córdoba Province) in the Obejo-Valsequillo-Puebla de la Reina Domain (Sierra Morena, Southern Spain) were investigated. The 71 stromatoporoid specimens collected belong to 11 different species.

The "Peñón Cortado" section in the Córdoba Province contains two different stromatoporoid-bearing horizons with very different fauna (bed 14 and bed 19b). In the older bed 14 dominates Plectostroma salairicum (Javorskij, 1930), meanwhile in the younger bed 19b Actinostroma compactum Ripper, 1933 and Pseudotrupetostroma anacontentoae May, 2005b dominate. The fauna of the younger bed 19b of the location "Peñón Cortado" correlate well with the stromatoporoid-bearing beds of the locations "Guadámez II" and "La Chamorra" in the Badajoz Province.

The absence of stromatoporoids with branched skeletons and the scarcity of stromatoporoids of the type which forms thin-layered crusts probably inhibited reef development. A possible explanation for this may be a relatively low water temperature.

Biogeographically, the fauna of the Sierra Morena belong to the Old World Realm and is closely related to Emsian fauna of Australia and Canada. The fauna indicate an Emsian age for the stromatoporoid-bearing beds in the "Peñón Cortado Limestone". Furthermore, the stromatoporoids from the locations "Guadámez II" and "La Chamorra" suggest an Upper Emsian age much more strongly than a Lower Emsian age.
\end{abstract}

Keywords: Stromatoporoidea, reefs, Obejo-Valsequillo-Puebla de la Reina Domain, Devonian, Emsian, Biostratigraphy, Biogeography, Spain.

\section{RESUMEN}

Se han estudiado los estromatoporoideos de tres localidades en las "Calizas del Peñón Cortado" (Pragiense a Emsiense superior) de la cuenca de Quintana de la Serena (prov. de Badajoz) y Peñarroya-Pueblonuevo (prov. de Córdoba) en el Dominio Obejo-Valsequillo-Puebla de la Reina (Sierra Morena, Sur de España). Los 71 ejemplares de estromatoporoideos recogidos pertenecen a 11 especies diferentes.

La sección de la localidad "Peñón Cortado" en la provincia de Córdoba contiene dos horizontes diferentes con estromatoporoideos, que representan faunas muy distintas: En el horizonte más antiguo, nivel 14, domina Plectostroma salairicum (Javorskij, 1930), mientras que en el horizonte más moderno, nivel 19b, situado $51 \mathrm{~m}$ por encima de la capa 14, dominan Actinostroma compactum Ripper, 1933 y Pseudotrupetostroma anacontentoae May, 2005b. La fauna de este último nivel se correlaciona muy bien con los horizontes con estromatoporoideos de las localidades "Guadámez II" y "La Chamorra" de la provincia de Badajoz.

La ausencia de estromatoporoideos con esqueletos ramifi cados y la escasez de estromatoporoideos que se incrustaban en capas fi nas inhibieron, probablemente, la construcción de arrecifes. Una explicación posible podría ser en relación con una temperatura relativamente baja del agua. 
Biogeográficamente, la fauna de estromatoporoideos de Sierra Morena pertenece al Reino del Mundo Viejo (Old World Realm) y presenta afinidades muy estrechas con las faunas del Emsiense de Australia y Canadá. Dicha fauna indica una edad Emsiense para los horizontes con estromatoporoideos en las "Calizas del Peñón Cortado". Además, los estromatoporoideos de las localidades "Guadámez II" y "La Chamorra" en la provincia de Badajoz sugieren con más fuerza una edad Emsiense superior que una Emsiense inferior.

Palabras clave: estromatoporoideos, arrecifes, Dominio Obejo-Valsequillo-Puebla de la Reina, Devónico, Emsiense, Bioestratigrafía, Biogeografía, España.

\section{INTRODUCTION}

Despite of some modern monographic treatments (e.g.: Webby et al., 1993; Webby \& Zhen, 1993; Prosh \& Stearn, 1996; Webby \& Zhen, 1997; May, 2005a), little is known of the evolution of stromatoporoids during the Lower Devonian epoch. During this epoch, in the time between the Silurian reefs and the huge Givetian-Frasnian reefs, both stromatoporoids and reefs were rather scarce.

On the other hand, the Sierra Morena in Southern Spain was known to contain Lower Devonian biostromal and biohermal limestones with both corals and stromatoporoids (Rodríguez García, 1978; Moreno-Eiris et al., 1995; García-Alcalde et al., 2002). However, these stromatoporoids of the Sierra Morena have never been examined in detail. Consequently, it was fortunate for me that Prof. Dr.
Sergio Rodríguez (Madrid) invited me to investigate them. This paper includes results of our current investigations.

\section{STUDY AREA}

The study area lies in the northern part of the ObejoValsequillo-Puebla de la Reina Domain (OVPRD) in the Sierra Morena in Southern Spain. The most recent overview of the Devonian of the OVPRD was given by GarcíaAlcalde et al. (2002: 82).

In the part of the OVPRD investigated, the Devonian succession commences with sandstones and shales, overlain by Emsian siltstones with calcareous beds. These calcareous beds are named "Peñón Cortado Limestone" (Rodríguez García, 1978; Moreno-Eiris et al., 1995). They contain abun-

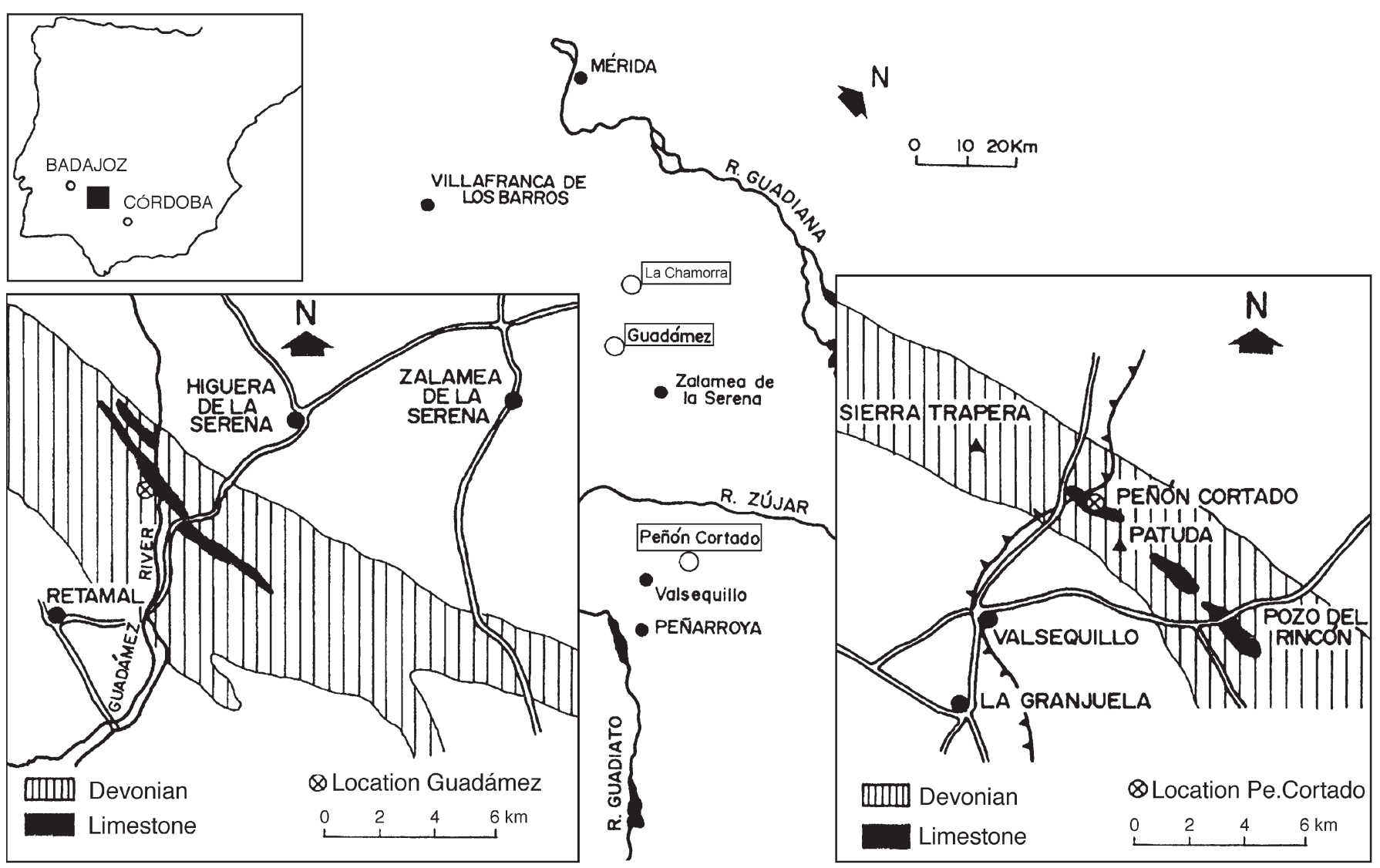

Figure 1. Geographical positions of the investigated locations in the Sierra Morena (modified after Moreno-Eiris et al., 1995). 
dant tabulate corals, common rugose corals, and stromatoporoids. A part of these calcareous beds are biostromes. Other beds were interpreted as being products of the destruction of buildups. However, no true buildups were recorded in the study area (Moreno-Eiris et al., 1995: 19).

Rodríguez García (1978) and Moreno-Eiris et al. (1995) assign an Upper Emsian age to the "Peñón Cortado Limestone". However, Miguel V. Pardo Alonso (Universitat de València, oral communication) found in the lower part of the "Peñon Cortado" section brachiopods of the Pragian.

A detailed description of all investigated locations in the "Peñón Cortado Limestone" is provided by Rodríguez García (1978). Furthermore, an updated description of the locations "Peñón Cortado" and "Guadámez II" is provided by Moreno-Eiris et al. (1995: 43-44). Consequently, the following contains only a short description of the locations. The geographical position of the locations is shown in figure 1 .

\section{Location "Guadámez II"}

The "Guadámez II" section is located in the Badajoz province on the western bank of the Guadámez River, two kilometres to the northwest of kilometre 12 of the road from Campillo de Llerena to Higuera de la Serena. The outcropping sequence, some 85 metres thick, of fossiliferous limestones and marls was subdivided into 22 beds by Rodríguez García (1978) and Moreno-Eiris et al. (1995). A lithostratigraphical column of the location is given in figure 2. Miguel V. Pardo Alonso (oral communication) found in the upper part of the sequence brachiopods of probable Upper Emsian age.

All 32 stromatoporoid specimens were collected from bed 19 and, directly below, from the uppermost metre of bed 18. Bed 19 is a massive limestone, 3.5 metres thick, consisting of a biostrome. Bed 18 is a marlstone, 7 metres thick, which contains in its uppermost metre many Thamnopora layers and laminar reef-builders (favositids and stromatoporoids). Favositids and stromatoporoids increase in importance upwards towards the top of bed 19 where bulbous stromatoporoids dominate.

The stromatoporoids belong to the species Actinostroma compactum Ripper, 1933, Schistodictyon n. sp. aff. amygdaloides (Lecompte, 1951), Stromatoporella granulata (Nicholson, 1873), Clathrocoilona sp., Stromatopora ex gr. polaris (Stearn, 1983), Pseudotrupetostroma anacontentoae May, 2005b, Syringostromella zintchenkovi (Chalfina, 1960), and Parallelostroma sinense Yang \& Dong, 1979. In the lower part of bed 19 prevail the stromatoporoids Stromatopora ex gr. polaris (Stearn, 1983) and Pseudotrupetostroma anacontentoae (May, 2005b), while in the upper part of bed 19 Actinostroma compactum (Ripper, 1933) and Parallelostroma sinense Yang \& Dong, 1979 prevail. Remarkable is the occurrence of the syringoporid tabulate coral Syringocystis sp. in the upper part of bed 19. Bed 19 contains small amounts of the cal- careous alga Rothpletzella spec. and crusts of spongiostromate calcareous algae.

The material is relatively well preserved and shows only very slight tectonic deformation.

\section{Location "La Chamorra"}

The outcrop "La Chamorra" is located in the Badajoz province, 4 kilometres to the northnorthwest of kilometre 4 of the road from Valle de la Serena to Puebla de la Reina. The outcrop is between "Cerro del Membrillo" and "Cerro Paliza" on the southwestern slope of the hill. (It is in the southernmost of the two northern limestone bands on the geological map.) It is few hundreds meter southeast of the profile published by Rodríguez García (1978: fig. 2). Because of the poor preservation of the outcrop a direct comparison with the profile of Rodríguez García (1978: fig. 2 ) is not possible. However, it is clear that the collected material is from the upper part of this sequence.

The limestones contain abundant different types of tabulate corals (favositids, alveolitids, coenitids, and heliolitids). Stromatoporoids and solitary rugose corals are frequent. Bryozoans and cerioid rugose corals are relatively rare. A large part of the 23 stromatoporoid skeletons collected is more or less strongly affected by recrystallization and/or tectonic deformation. Nevertheless, it was possible to identify the following species: Actinostroma cf. stellulatum Nicholson, 1886, Stromatopora ex gr. polaris (Stearn, 1983), Pseudotrupetostroma anacontentoae May, 2005b?, Salairella sp., and Syringostromella zintchenkovi (Chalfina, 1960).

\section{Location "Peñón Cortado"}

The "Peñon Cortado" section is located in the Córdoba province, 5 kilometres north of Valsequillo, at the Córdoba-Almorchón railway cutting (at kilometre 35.5 of the railway). The outcropping sequence, some $110 \mathrm{~m}$ thick, consists of fossiliferous limestones, marls, and shales. A subdivision of the section into 19 beds was made by Rodríguez García (1978) and Moreno-Eiris et al. (1995). A lithostratigraphical column of the location is given in figure 2. Miguel V. Pardo Alonso (oral communication) found in the lower part of the sequence brachiopods of the Pragian; however, an Emsian age of the stromatoporoid-containing beds (which are located in the middle and upper part of the sequence) is possible.

Despite the great effort made in the search for stromatoporoids, it was only possible to find them in the beds 14 and 19b. However, instead of stromatoporoids, fistuliporid bryozoans occur in the base of bed 9 and in bed 12 .

In bed 14 were found eleven stromatoporoid specimens. Dominating among the stromatoporoids is Plectostroma salairicum (Javorskij, 1930), Syringostromella zintchenkovi (Chalfina, 1960) occurs only rarely. Bed 14 is a $13.5 \mathrm{~m}$ thick, massive limestone with large colonies of favositids, stromatoporoids, and the colonial rugose 


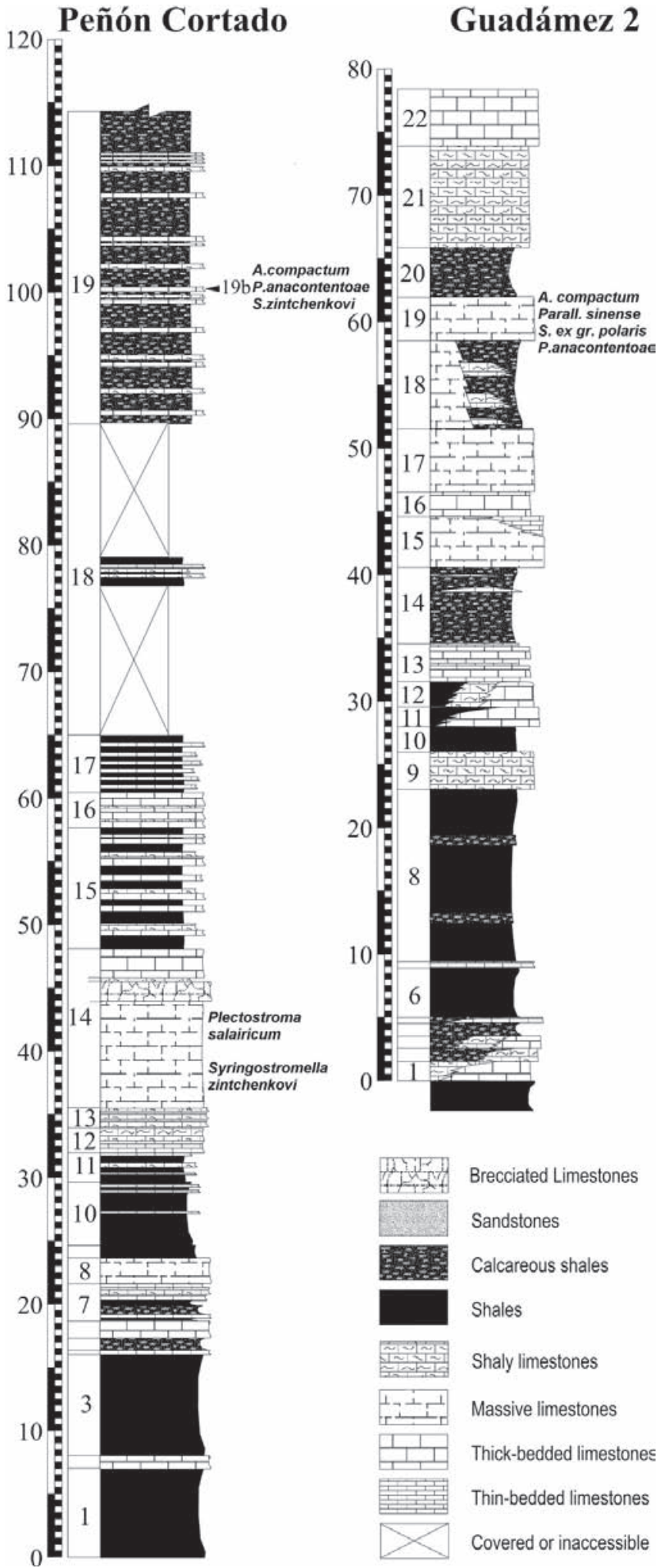

coral Hexagonaria soraufi Rodríguez García, 1978. In some parts auloporid tabulate corals and bryozoans occur. Moreno-Eiris et al. (1995: p. 44) regarded bed 14 as a product of the destruction of build-ups.

Five stromatoporoids, belonging to the species Actinostroma compactum Ripper, 1933, Pseudotrupetostroma anacontentoae May, 2005b, and Syringostromella zintchenkovi (Chalfina, 1960), were collected from bed 19b, a $1.5 \mathrm{~m}$ thick layer of thick-bedded limestone $10 \mathrm{~m}$ above of the base of bed 19. Bed 19b is about $51 \mathrm{~m}$ above the top of bed 14 .

All collected stromatoporoids are relatively well preserved and show only very slight tectonic deformation.

\section{MATERIAL AND METHODS}

Longitudinal (=vertical) and tangential thin sections have been taken from all stromatoporoid specimens collected. A list of the species found and the number of specimens of each species is given in table 1 . The most important species are represented in figure 3 . The methodology, terminology, and classification (including the genus definitions) follow those of Stearn $e t$ al. (1999). The material is stored in the Departamento de Paleontología, Universidad Complutense, Madrid.

\section{STRATIGRAPHICAL CORRELATION BETWEEN THE LOCATIONS BY STROMATOPOROID SPECIES}

One important question for our investigations is: how can the location "Peñón Cortado" (Córdoba province) be correlated to the locations in the Badajoz province? Be-

Figure 3. Important stromatoporoids of the "Peñón Cortado Limestone" (Emsian) in the OVPRD in the Sierra Morena. The scale is always $1 \mathrm{~mm}$ long. a, Actinostroma compactum Ripper, 1933, longitudinal section (DPM-00276/S11); location "Guadámez II". b, Plectostroma salairicum (Javorskij, 1930), longitudinal section (DPM-00276/S1); location "Peñón Cortado". c, Schistodictyon n. sp. aff. amygdaloides (Lecompte, 1951), longitudinal section (DPM-00276/S6); location "Guadámez II". d, Clathrocoilona sp., longitudinal section (rotated by $90^{\circ}$ ) (DPM-00276/S16); location "Guadámez II". e, Pseudotrupetostroma anacontentoae May, 2005b, longitudinal section (holotype, DPM-00276/S15); location "Guadámez II". f, Pseudotrupetostroma anacontentoae May, 2005b, tangential section (holotype, DPM-00276/S15); location "Guadámez II". g, Stromatopora ex gr. polaris (Stearn, 1983) longitudinal section (DPM-00276/S9); location "Guadámez II". h, Syringostromella zintchenkovi (Chalfina, 1960), longitudinal section (DPM00276/S3); location "Peñón Cortado". i, Parallelostroma sinense Yang \& Dong, 1979, longitudinal section (DPM-00276/S7); location “Guadámez II”. 
等然 4 (3)

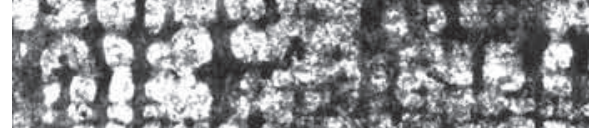
ato. 15

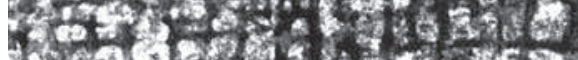

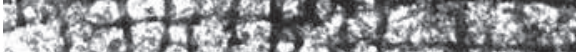

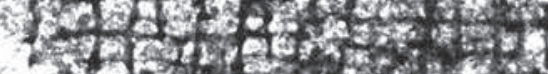

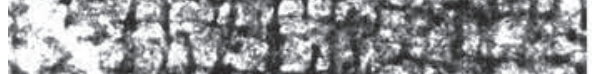

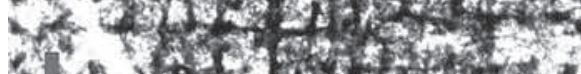

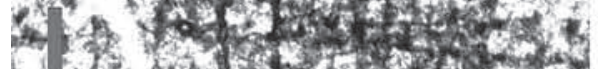
$\sum_{1}^{2}$ s. 6. 36. (1)

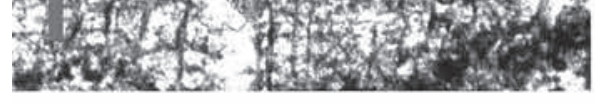

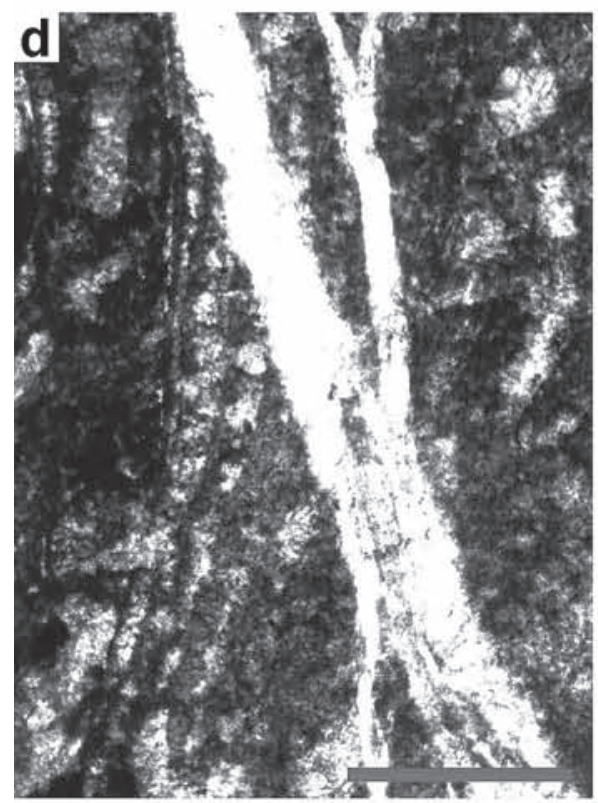

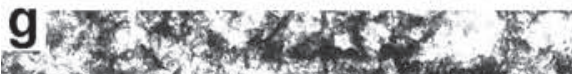

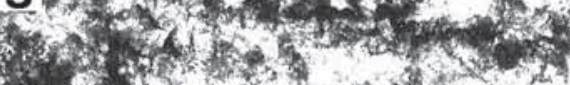

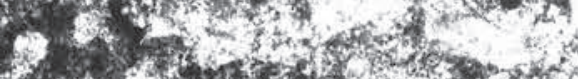

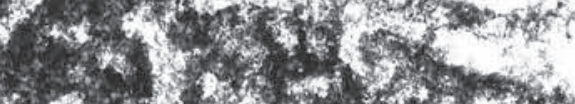

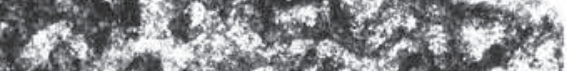

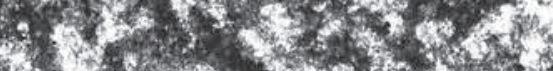
30 -n.t.

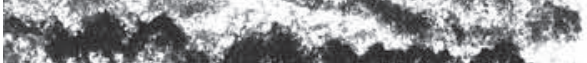

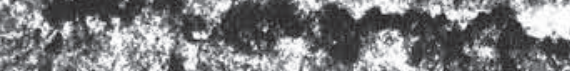

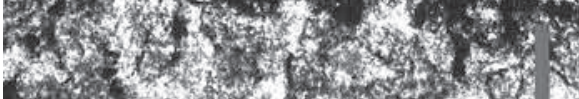

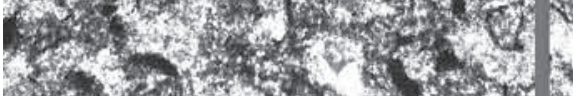
2.6.213.

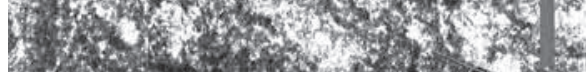

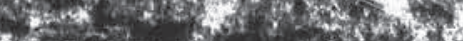

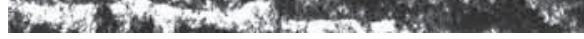

b

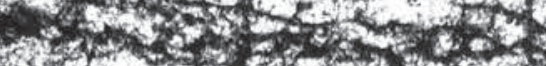

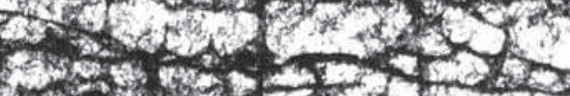

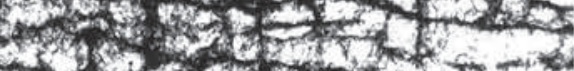

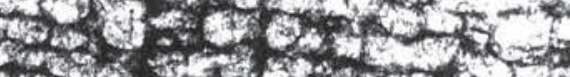

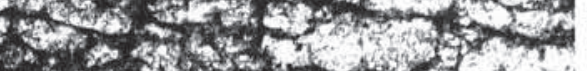

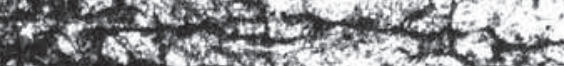
T. 120 .

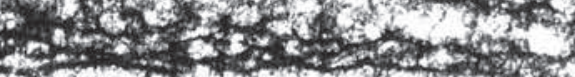

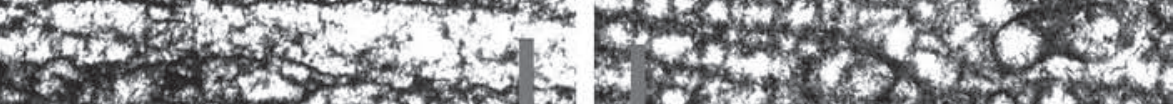

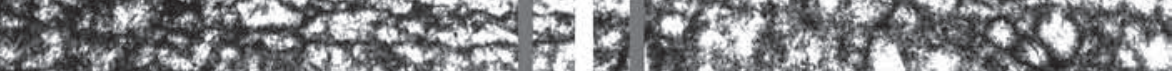

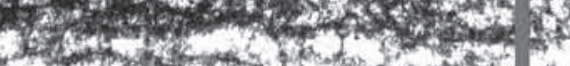

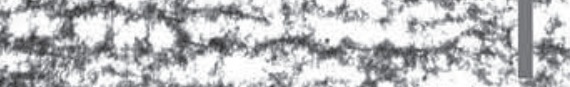

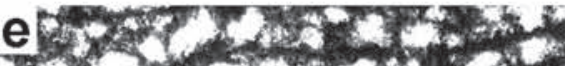

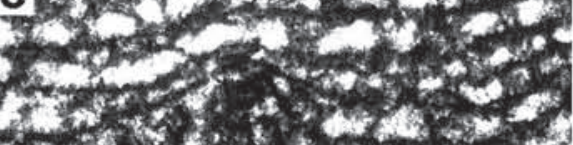

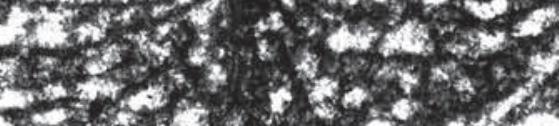

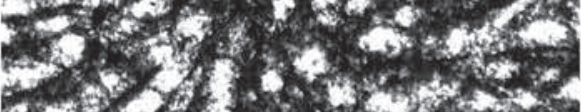

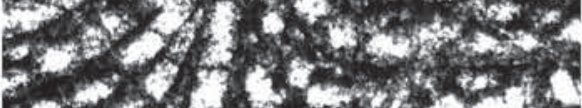

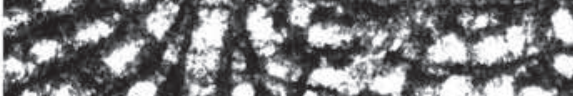

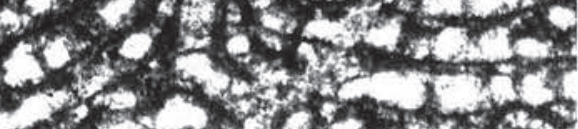

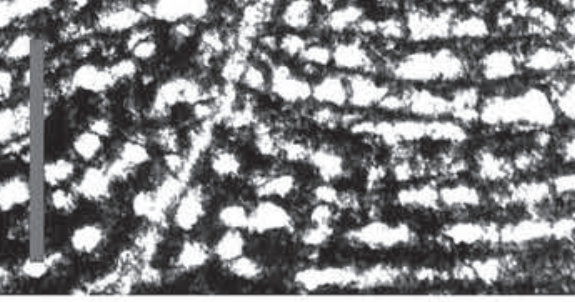

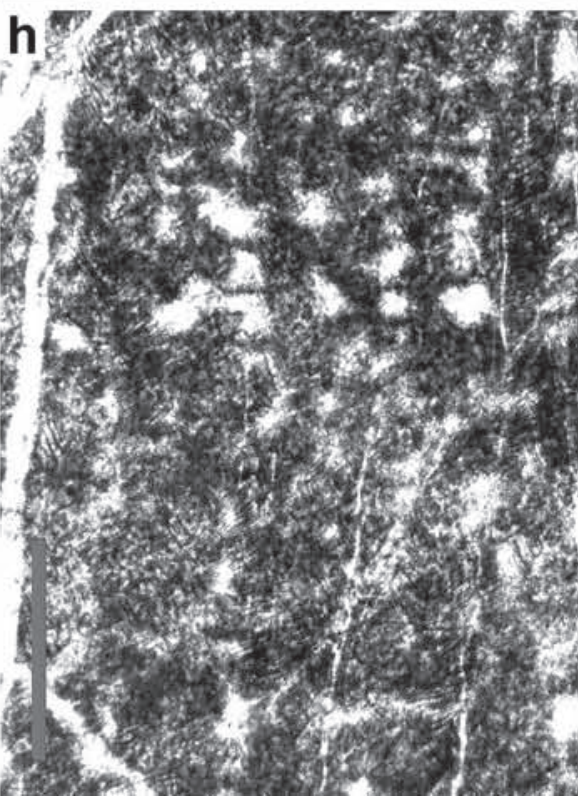

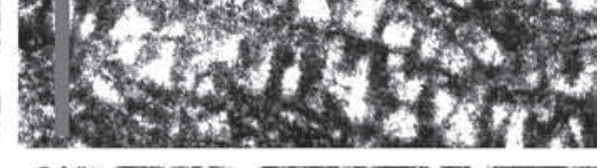

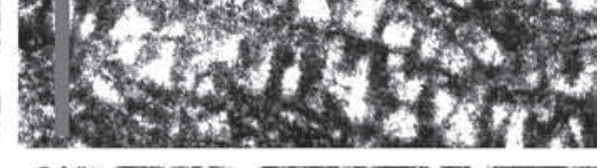

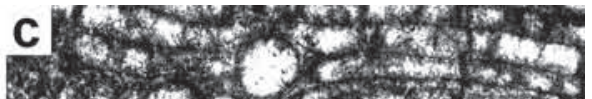
1.

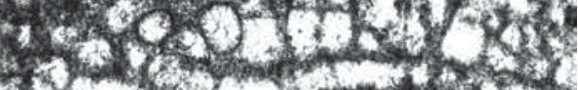

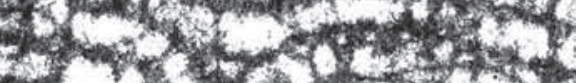
5 and

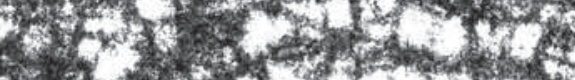

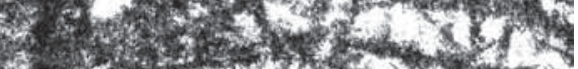

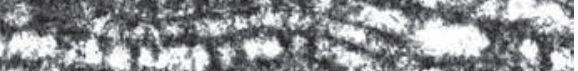

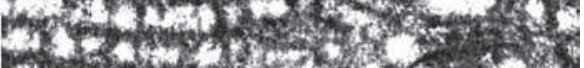

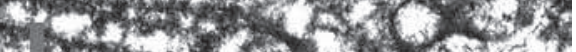

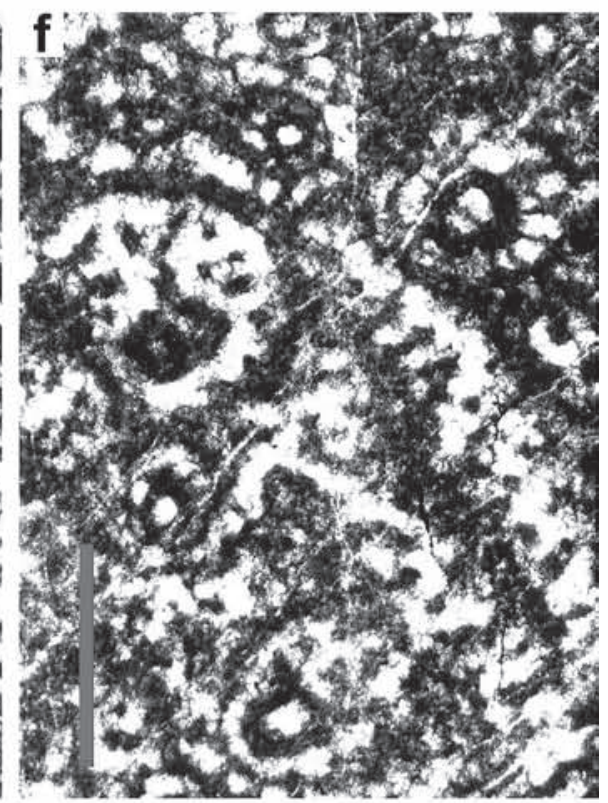
i

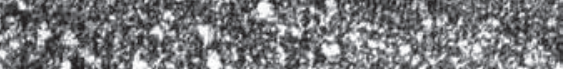
W a

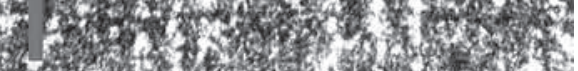

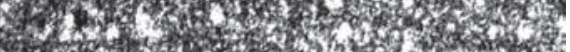

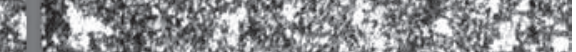


tween "Peñón Cortado" and the locations in the Badajoz province is a distance of about 54 kilometres. Intuitively one might expect that the stromatoporoid-bearing beds in the Badajoz province are equivalent to the thick fossiliferous bed 14 of the location "Peñón Cortado" (Fig. 2).

Table 1 shows clearly, that bed 14 of the location "Peñón Cortado" has only the ubiquitous Syringostromella zintchenkovi (Chalfina, 1960) in common with the stromatoporoid-bearing beds of the locations "Guadámez II" and "La Chamorra" in the Badajoz province. The dominant stromatoporoid of bed 14, Plectostroma salairicum (Javorskij, 1930), occurs only here. Consequently, bed 14 of the location "Peñón Cortado" can not be stratigraphically correlated to the stromatoporoid-bearing beds of the locations in the Badajoz province.

However, the younger bed $19 \mathrm{~b}$ of the location "Peñón Cortado" (Fig. 2) correlates very well to the location "Guadámez II" in the Badajoz province, because Actinostroma compactum Ripper, 1933 and Pseudotrupetostroma anacontentoae May, 2005b are the dominant stromatoporoids in the bed 19 (and in the uppermost part of bed 18) of the location "Guadámez II" as well as in the bed 19b of the location "Peñón Cortado".

The correlation of the stromatoporoid-bearing beds of the location "La Chamorra" to the bed 19 of the location "Guadámez II" and the bed 19b of the location "Peñón Cortado" can be justified by following observations:

- Stromatopora ex gr. polaris (Stearn, 1983) and Pseudotrupetostroma anacontentoae May, 2005b occur in the location "La Chamorra" as well as in the location "Guadámez II". (Unfortunately, the P. anacontentoae of "La Chamorra" is poorly preserved.)

- Actinostroma cf. stellulatum Nicholson, 1886, the dominant stromatoporoid of the location "La Chamorra", is closely related to Actinostroma compactum Ripper, 1933.

To continue, bed 19b of the location "Peñón Cortado" can be correlated stratigraphically with bed 19 (and the

\begin{tabular}{|c|c|c|c|c|c|c|c|}
\hline Species in the Sierra Morena & $\begin{array}{l}\text { Peñón Cor. } \\
\text { - Bed } 14\end{array}$ & $\begin{array}{l}\text { Peñón Cor. } \\
\text { - Bed 19b }\end{array}$ & $\begin{array}{l}\text { Guadámez } \\
\text { II }\end{array}$ & $\begin{array}{l}\text { La Cha- } \\
\text { morra }\end{array}$ & Bohemia & Victoria & Canada \\
\hline $\begin{array}{l}\text { Actinostroma compactum Ripper, } \\
1933\end{array}$ & - & 2 specimens & $\begin{array}{c}10 \\
\text { specimens }\end{array}$ & - & Genus & Species & Genus \\
\hline $\begin{array}{l}\text { Actinostroma cf. stellulatum } \\
\text { Nicholson, } 1886\end{array}$ & - & - & - & $\begin{array}{c}10 \\
\text { specimens }\end{array}$ & Genus & Genus & Genus \\
\hline $\begin{array}{l}\text { Plectostroma salairicum (Javorskij, } \\
\text { 1930) }\end{array}$ & $\begin{array}{c}10 \\
\text { specimens }\end{array}$ & - & - & - & Genus & Genus & Species \\
\hline $\begin{array}{l}\text { Schistodictyon n. sp. aff. } \\
\text { amygdaloides (Lecompte, 1951) }\end{array}$ & - & - & 2 specimens & - & Genus & Genus & Genus \\
\hline $\begin{array}{l}\text { Stromatoporella granulata } \\
\text { (Nicholson, 1873) }\end{array}$ & - & - & 1 specimen & - & Genus & Genus & Genus \\
\hline Clathrocoilona sp. & - & - & 3 specimens & - & - & - & Genus \\
\hline $\begin{array}{l}\text { Stromatopora ex gr. polaris } \\
\text { (Stearn, 1983) }\end{array}$ & - & - & 3 specimens & 3 specimens & - & Species & Species \\
\hline $\begin{array}{l}\text { Pseudotrupetostroma } \\
\text { anacontentoae May, 2005b }\end{array}$ & - & 2 specimens & 7 specimens & $\begin{array}{l}1 \text { doubtful } \\
\text { specimen }\end{array}$ & - & Genus & - \\
\hline Salairella sp. & - & - & - & 3 specimens & Genus & Genus & Genus \\
\hline $\begin{array}{l}\text { Syringostromella zintchenkovi } \\
\text { (Chalfina, 1960) }\end{array}$ & 1 specimen & 1 specimen & 1 specimen & 2 specimens & Genus & Species & Species \\
\hline $\begin{array}{l}\text { Parallelostroma sinense Yang \& } \\
\text { Dong, } 1979\end{array}$ & - & - & 5 specimens & - & - & - & - \\
\hline Indeterminable stromatoporoids & - & - & - & 4 specimens & & & \\
\hline Total number of specimens & 11 & 5 & 32 & 23 & & & \\
\hline
\end{tabular}

Table 1. Compilation of the stromatoporoid species found in the OVPRD in the Sierra Morena. The columns "Peñón Cortado Bed 14" to "La Chamorra" give the number of specimens collected there. To the right there follows a comparison of the stromatoporoid fauna of the OVPRD with the stromatoporoid fauna of the Middle Pragian of Bohemia (May, 1999, 2002, 2005a), the Pragian to Lower Emsian of Victoria (Australia) (Webby et al., 1993) and the Lower Emsian to Lower Eifelian of Arctic Canada (Prosh \& Stearn, 1996). The entry "Species" signifies that the same species occurs as in the OVPRD. The entry "Genus" signifies that the same genus occurs as that of the OVPRD, although not the same species. 
uppermost part of bed 18) of the location "Guadámez II" and the stromatoporoid-bearing beds of the location "La Chamorra".

\section{BIOSTRATIGRAPHY AND BIOGEOGRAPHY}

\section{Literature data of the found stromatoporoid species}

Descriptions of Actinostroma compactum Ripper, 1933 were given by Webby et al. (1993: 123-125), Webby \& Zhen (1997: 17) and May (1999b: 99-100). Beside its occurrence in the OVPRD in the Sierra Morena, Actinostroma compactum has not been found outside the Pragian and Lower Emsian of Victoria and Queensland in Australia (Webby et al., 1993; Webby \& Zhen, 1997).

Actinostroma stellulatum Nicholson, 1886 occurs widespread in the Eifelian to Frasnian of Europe, Asia and Australia (Lecompte, 1951: 111-118; May, 1993: 29-30). Furthermore it is known from the late Emsian to early Eifelian of the Cantabrian Mountains (Méndez-Bedia, 1999: 124). Webby \& Zhen (1993: 331-332; 1997: 16-17) describe closely related material from the Upper Emsian of New South Wales and Queensland (Australia) as Actinostroma aff. stellulatum.

Descriptions of Plectostroma salairicum (Javorskij, 1930) by Javorskij (1930: 489-490) and Prosh \& Stearn (1996: 15-16) prove the occurrence of the species in the uppermost Emsian and lowermost Eifelian of Western Siberia and in Arctic Canada. Beside the occurrence in the uppermost Emsian and lowermost Eifelian, Stearn (2001: fig. 1) indicates a doubtful occurrence of Plectostroma salairicum in a middle part of the Emsian in Canada.

Schistodictyon n. sp. aff. amygdaloides (Lecompte, 1951) has been described by May (1999b: 100-101) from the the location "Guadámez II". It is similar to Schistodictyon amygdaloides (Lecompte, 1951), which occurs in the Lower Eifelian to Lower Givetian beds of Belgium, Germany, and Australia (Lecompte, 1951: 141-145; Avlar \& May, 1997: 108-109).

Stromatoporella granulata (Nicholson, 1873) is known from the Eifelian and Givetian of Belgium, France, Moravia, Siberia, and Canada (Lecompte, 1951: 160-163; May, 1993: 32-33). Sleumer (1969: 38-40) describes Stromatoporella granulata (Nicholson, 1873) from the late Emsian to the Givetian of the Cantabrian Mountains.

The encrusting stromatoporoid genus Clathrocoilona Javorskij, 1931 is distributed worldwide in the reef complexes of the Middle Devonian and Frasnian. First occurrences were reported from Emsian beds in Canada, Austria, and Russia (Prosh \& Stearn 1996: 28-30; Stearn et al., 1999: 39).

Stromatopora polaris (Stearn, 1983) has been found in the Emsian of Canada (Stearn, 1983: 551-552; Stearn, 1990: 507; Prosh \& Stearn, 1996: 31; Stearn, 2001: 14-
15). However, a very closely related form from the Lower Emsian of Victoria (Australia) was described as Stromatopora aff. polaris (Stearn, 1983) by Webby et al. (1993: 158-161).

Pseudotrupetostroma anacontentoae May, 2005b is up to now only known from the OVPRD (May, 2005b). The genus Pseudotrupetostroma Chalfina \& Javorskij, 1971 is known from the Emsian to the Givetian in Australia, Asia, and Canada (Stearn et al., 1999: 48).

Descriptions of Syringostromella zintchenkovi (Chalfina, 1960) are given by Chalfina (1960: 327-328), Webby et al. (1993: 163), and Prosh \& Stearn (1996: 34). Hitherto Syringostromella zintchenkovi has been found in the Upper Lochkovian of Russia (Chalfina, 1960: 327-328), the Pragian of Victoria (Australia) (Webby et al., 1993: 163), and the Lower Emsian of Arctic Canada (Prosh \& Stearn, 1996: 34).

Salairella Chalfina, 1960 occurs from the Pragian to the Frasnian in Australia, Canada, Asia, and Europe (Stearn et al., 1999: 51; Stearn, 2001: 10-11; May, 2005a: 14, 84-90).

Parallelostroma sinense Yang \& Dong, 1979 is described by Yang \& Dong (1979: 73) from the Emsian of Guangxi (China). Dong \& Wang (1989: 272, 290) found Parallelostroma sinense Yang \& Dong, 1979 in the early Middle Devonian of Guangxi (China).

\section{Age of the stromatoporoid-bearing beds}

Compiling the known stratigraphical distributions of the species found, the different stromatoporoid faunas always indicate an Emsian age for the stromatoporoid-bearing beds in the "Peñón Cortado Limestone". Even in the case of bed 14 of the "Peñón Cortado" section, where only two species occur, the occurrence of Syringostromella zintchenkovi (Chalfina, 1960) with a stratigraphical range from Upper Lochkovian to Lower Emsian is counterbalanced by the stratigraphical range of Plectostroma salairicum (Javorskij, 1930) from a middle part of the Emsian to the lowermost Eifelian.

Furthermore, the fauna of bed 19 (and the uppermost part of bed 18) of the location "Guadámez II" and the stromatoporoid-bearing beds of the location "La Chamorra" suggest much more an Upper Emsian age than a Lower Emsian age. This results from several species and genera whose stratigraphical range commences in the (Upper) Emsian (or Lower Eifelian) with a main distribution in the Middle Devonian [Actinostroma stellulatum Nicholson, 1886, Schistodictyon amygdaloides (Lecompte, 1951), Stromatoporella granulata (Nicholson, 1873), Clathrocoilona Javorskij, 1931, Pseudotrupetostroma Chalfina \& Javorskij, 1971, Parallelostroma sinense Yang \& Dong, 1979].

Indeed, the dating of the stromatoporoids is consistent with the stratigraphical assignment of Rodríguez García (1978) and Moreno-Eiris et al. (1995). The brachiopods 
found by Miguel V. Pardo Alonso (oral communication) fit in this picture: He found in the upper part of the sequence of the location "Guadámez II" brachiopods of probable Upper Emsian age. Even the fact, that he found in the lower part of the "Peñón Cortado" section brachiopods of the Pragian, does not speak against an Emsian age of the stromatoporoid-bearing beds in the middle to upper part of the sequence.

The occurrence of the syringoporid tabulate coral Syringocystis $\mathrm{sp}$. in the upper part of bed 19 of the location "Guadámez II" supports the stratigraphical assignment and the biogeographical classification made by the stromatoporoids, because Syringocystis Deng, 1966 is known from the Emsian, Eifelian, and Givetian of Europe and Asia (Birenheide, 1985: 131-135).

\section{Biogeography}

All genera found in the OVPRD in the Sierra Morena are known from beds of Emsian age in other parts of the Old World Realm (Stearn et al., 1999). The Old World Realm extended from Australia over Asia and Europe to Canada (Boucot, 1988; Pedder \& Oliver, 1990; Stock, 1990, 1997). Almost all stromatoporoid species collected in the OVPRD are not known from other parts of Spain. Nevertheless, almost all species are known from beds of Emsian age in other parts of the Old World Realm. Furthermore, the closest relatives of Schistodictyon $\mathrm{n}$. sp. aff. amygdaloides (Lecompte, 1951) and Pseudotrupetostroma anacontentoae May, 2005b lived in the Old World Realm.

On the other hand, the fauna of the OVPRD do not show any relation to that of the Eastern Americas Realm: The stromatoporoid fauna of the Eastern Americas Realm are characterized by the occurrence of Habrostroma and by the absence of species of the order Actinostromatida (Stock, 1990: 258; Stock, 1994; Stock, 1997: 285). However, the stromatoporoid fauna of the Sierra Morena do not contain any Habrostroma, but with Actinostroma compactum Ripper, 1933 and Plectostroma salairicum (Javorskij, 1930) two species of the order Actinostromatida.

After establishing the classification within the Old World Realm, the logical next step is to compare the stromatoporoid fauna of the OVPRD with faunas from recently investigated sites of Lower Devonian age in other parts of the Old World Realm. However, it is not easy to find stromatoporoid-bearing sites, whose Lower Devonian stromatoporoid fauna are sufficiently well investigated. For example, it is well known, that the Cantabrian Mountains (Northern Spain) contain rich Lower Devonian stromatoporoid fauna. Nevertheless, these fauna are insufficiently known, because the publication of Sleumer (1969) is outdated, the publication of Méndez-Bedia (1984) is a short notice, Méndez-Bedia \& Mistiaen (1997) describe only species of Stromatoporella in open nomenclature and Méndez-Bedia (1999) describes only species of Actinostroma.
As a consequence of similar circumstances only one Lower Devonian stromatoporoid-bearing site in Europe is appropriate for a comparison with the stromatoporoid fauna of the OVPRD: the Middle Pragian of Central Bohemia. On a world-wide level the situation is not much better, so that I elected the following recently investigated Lower Devonian stromatoporoid-bearing sites in the Old World Realm for a comparison:

- Middle Pragian of Central Bohemia (May, 1999a, 2002, 2005a);

- Pragian to Lower Emsian of Victoria (Australia) (Webby et al., 1993);

- Lower Emsian to Lower Eifelian of Arctic Canada (Prosh \& Stearn, 1996).

Table 1 compares the stromatoporoid faunas of these three sites with the stromatoporoid fauna of the OVPRD.

The stromatoporoid fauna of the OVPRD display the least amount of conformity with the Middle Pragian of Bohemia, in spite of the small geographical distance between them. This is probably a result of the stratigraphical distance between them.

However, the stromatoporoid fauna of the OVPRD display a high level of conformity with the more or less synchronous fauna in Victoria (Australia) and Arctic Canada. Such close connections between very distant sites are most remarkable because the Emsian was the time of the strongest faunal provincialism during the Devonian period (Boucot, 1988: 211-212, 219; Pedder \& Oliver, 1990: 267; Oliver \& Pedder, 1994: 185; May, 1995: 39; May, 1997: 293). Nevertheless, it would be rash to construct migratory pathways for stromatoporoids based on these observations; because it is possible, that the Lower Devonian stromatoporoids were generally more cosmopolitic than several other groups of benthos organisms - this phenomenon is known from Middle Devonian stromatoporoids (Stock, 1990: 264; May, 1997: 298-299).

\section{PALEOECOLOGY}

In the Lower Devonian of the OVPRD in the Sierra Morena, stromatoporoids occur only in very few beds. The comparison of the different beds in the three investigated locations and a fourth locality without stromatoporoids (outcrop "Arroyo del Lobo" south of Monterrubio de la Serena, Badajoz province) shows clearly, that the stromatoporoids were immediately substituted by encrusting bryozoans (e.g. fistuliporids), if the environment was not conducive to them. This observation is remarkable, because the same pattern can be observed within the Pragian reef complex of Koneprusy (Bohemia) (May, 2005a). On the other hand, Middle Devonian reef complexes normally don't show such a substitution of stromatoporoids by encrusting bryozoans. 
In the OVPRD, stromatoporoids with branched skeletons are totally absent and stromatoporoids of the type which forms thin-layered crusts are very rare. (Only the Clathrocoilona from "Guadámez II" formed thin-layered crusts). However, these same growth forms occur nearly everywhere in the Givetian-Frasnian reefs. Perhaps these morphotypes of stromatoporoids were very important for the Givetian-Frasnian reefs, and their absence in the Lower Devonian of the OVPRD was a reason for the absence of true reefs in the OVPRD. Furthermore, up to now no stromatoporoid specimen with Syringopora commensalism has been found in the OVPRD.

It is remarkable that May (2005a) describes the same patterns (abundance of bryozoans, absence of branched stromatoporoids, scarcity of stromatoporoids of the type which forms thin-layered crusts, and scarcity of Syringopo$\mathrm{ra}$ commensalism) from the Pragian reef complex of Koneprusy (Bohemia). As a possible explanation May (2005a) proposes a reduced water temperature. Similarly it is possible, that upwelling cold water hindered reef development in the OVPRD, as Carls (1999) assumed to be the case in the Lower Devonian of Central Spain. This hypothesis could also explain the large differences between the stromatoporoid fauna of bed 14 at location "Peñón Cortado" and the other (= younger) stromatoporoid fauna (bed 19b of location "Peñón Cortado", locations "Guadámez II" and "La Chamorra"; compare table 1). The explanation would be that bed 14 of "Peñón Cortado" section was built during a time of relatively low water temperature, while the diverse stromatoporoid fauna of bed 19b of "Peñón Cortado" section (and its equivalents in the Badajoz province) reflect a time of higher water temperature. Clearly, much more investigations are necessary to support or discard this hypothesis.

As a counter-argument to the hypothesis, that relatively low water temperatures in the OVPRD hindered reef development, one might state, that in Central Bohemia reef development was possible at relatively low water temperatures. However, it is only one reef, the Koneprusy reef, known, which is isolated and relatively small, and far away from any input of terrigenous sediments. The most important reef builders in the Pragian reef complex of Koneprusy are corals, stromatolites and solenoporacean calcareous algae (May, 2005a). Up to now, stromatolites and solenoporacean calcareous algae are not known from the Lower Devonian of the OVPRD - maybe the amount of sedimentary input was too high for them.

\section{ACKNOWLEDGEMENTS}

I am very grateful to Prof. Dr. Sergio Rodríguez (Madrid) for his manifold support of my research in the Sierra Morena. The research was supported by the research project BTE2003-02065 "Bioconstrucciones del Devónico del Dominio Obejo-Valsequil- lo y del Carbonífero del área del Guadiato" of the Ministerio de Educación y Ciencia. Furthermore, the English of the article was proof-read by Peter Brittain.

This article is a contribution to the IGCP 499 "Devonian landsea interaction: evolution of ecosystems and climate".

\section{REFERENCES}

Avlar, H. \& May, A. 1997. Zur Fauna und Stratigraphie der cultrijugatus-Schichten (Wende Unter-/Mittel-Devon) im West-Sauerland (Rheinisches Schiefergebirge). Coral Research Bulletin, 5, 103-119.

Birenheide, R. 1985. Chaetetida und tabulate Korallen des Devon. Leitfossilien, 3, 1-249.

Boucot, A. J. 1988. Devonian Biogeography: An Update. In: Devonian of The World, Volume III: Paleontology, Paleoecology and Biostratigraphy (eds. N. J. McMillan, A. F. Embry \& D. J. Glass). Canadian Society of Petroleum Geologists, Memoir, 14, 211-227.

Carls, P. 1999. El Devónico de Celtiberia y sus fósiles. In: Memorias de las VI Jornadas Aragonesas de Paleontología "25 años de Paleontología Aragonesa" (eds. J. A. Gámez Vintaned \& E. Liñán). Institución "Fernando el Católico", Zaragoza, 101-164.

Chalfina, V. K. 1960. Otrjad Stromatoporoidea. [Devonskaja sistema]. In: Biostratigrafija paleozoja Sajano-Altajskoj gornoj oblasti, Tom II, Srednij paleozoj (ed. L. L. Chalfin). Trudy sibirskogo naučno-issledovatel'skogo Instituta Geologii, Geofiziki i mineral'nogo Syr'ja (SNIIGGIMS), 20, 323-349, 602-633.

Dong Deyuan \& Wang Shubei 1989. Devonian stromatoporoid biota of northern Guangxi and mountlike superimposed bioherm of Huanjiang county - with remarks on the distribution of the Devonian and sedimentary paleogeography in this area. Memoirs of Nanjing Institute of Geology and Palaeontology, 26, 235-290.

García-Alcalde, J. L., Carls, P., Pardo Alonso, M. V., Sanz López, J., Soto, F., Truyols-Massoni, M. \& ValenzuelaRíos, J. I. 2002. Devonian. In: The Geology of Spain (eds. W. Gibbons \& T. Moreno). Geological Society, London, 67-91.

Javorskij, V. I. 1930. Actinostromidae iz devonskich otlozenij okrain Kuzneckogo bassejna i Urala. Izvestija geologiškovo komiteta, 49, 473-496.

Lecompte, M. 1951. Les stromatoporoides du Dévonien moyen et supérieur du bassin de Dinant. Première Partie. Institut royal des Sciences naturelles de Belgique, $\mathrm{Me}$ moires, 116, 1-216.

May, A. 1993. Stratigraphie, Stromatoporen-Fauna und Palökologie von Korallenkalken aus dem Ober-Eifelium und Unter-Givetium (Devon) des nordwestlichen Sauerlandes (Rheinisches Schiefergebirge). Geologie und Paläontologie in Westfalen, 24, 3-93.

May, A. 1995. Relationship among sea-level fluctuation, biogeography, and bioevents of the Devonian: an attempt to approach a powerful, but simple model for complex longrange control of biotic crises. Geolines, 3, 38-49. 
May, A. 1997. Gedanken über Zusammenhänge zwischen Meeresspiegel, Biogeographie und Bio-Events im Devon. Coral Research Bulletin, 5, 291-318.

May, A. 1999a. Revision of the Silurian and Devonian stromatoporoids of Bohemia described by Počta (1894). Journal of the Czech geological Society, 44, 167-180.

May, A. 1999b. Stromatoporen aus dem Ober-Emsium (Unter-Devon) der Sierra Moreno (Süd-Spanien). Münstersche Forschungen zur Geologie und Paläontologie, 86, 97-105.

May, A. 2002. Bisher noch nicht bekannte Stromatoporen aus dem Pragium (Unterdevon) von Koneprusy (Böhmen). Coral Research Bulletin, 7, 115-140.

May, A. 2005a. Die Stromatoporen des Devons und Silurs von Zentral-Böhmen (Tschechische Republik) und ihre Kommensalen. Zitteliana, B25, 117-250.

May, A. 2005b. Lower Devonian Stromatoporoids of the Sierra Morena (Southern Spain) and their Palaeogeographic Affinities. In: Proceedings 9th International Symposium on Fossil Cnidaria and Porifera. Schriftenreihe der Erdwissenschaftlichen Kommissionen der Österreichischen Akademie der Wissenschaften, 20 manuscript-p. [In press].

Méndez-Bedia, I. 1984. Primera nota sobre los estromatoporidos de la Formación Moniello (Devónico de la Cordillera Cantábrica, NW de España). Trabajos de Geología, 14, 151-159.

Méndez-Bedia, I. 1999. El género Actinostroma Nicholson (estromatoporoideos) en la Formación Santa Lucía (Dévonico, Cordillera Cantabrica, NO de España). Revista Española de Paleontología, extr. homenaje Prof. Truyols, 121-128.

Méndez-Bedia, I. \& Mistiaen, B. 1997. Genus Stromatoporella Nicholson, 1886 from the Cantabrian Mountains (Santa Lucía Formation, Lower-Middle Devonian, NW Spain). Boletín de la Real Sociedad Española de Historia Natural (Seccíon Geológica), 91, 343-353.

Moreno-Eiris, E., Perejón, A., Rodríguez, S. \& Falces, S. 1995. Paleozoic Cnidaria and Porifera from Sierra Morena. VII International Symposium on Fossil Cnidaria and Porifera, Madrid, Field Trip D, 68 pp.

Oliver, W. A. \& Pedder, A. E. H. 1994. Crises in the Devonian history of the rugose corals. Paleobiology, 20, 178-190.

Pedder, A. E. H. \& Oliver, W. A. 1990. Rugose coral distribution as a test of Devonian palaeogeographic models. In: Palaeozoic Palaeogeography and Biogeography (eds. W. S. McKerrow \& C. R. Scotese). Geological Society, Memoir, 12, 267-275, London.

Prosh, E. \& Stearn, C. W. 1996. Stromatoporoids from the Emsian (Lower Devonian) of Arctic Canada. Bulletins of American Paleontology, 109 (349), 5-66.
Rodríguez García, S. 1978. Corales rugosos del Devónico de la sierra del Pedroso. Estudios geologicos, 34, 331-350, Madrid.

Sleumer, B. H. G. 1969. Devonian Stromatoporoids of the Cantabrian Mountains (Spain). Leidse Geologische Mededelingen, 44, 1-136.

Stearn, C. W. 1983. Stromatoporoids from the Blue Fiord Formation (Lower Devonian) of Ellesmere Island, Arctic Canada. Journal of Paleontology, 57, 539-559.

Stearn, C. W. 1990. Stromatoporoids from the allochthonous reef facies of the Stuart Bay Formation (Lower Devonian), Bathurst Island, Arctic Canada. Journal of Paleontology, 64, 493-510.

Stearn, C. W. 2001. Biostratigraphy of Devonian stromatoporoid faunas of Arctic and Western Canada. Journal of Paleontology, 75, 9-23.

Stearn, C. W., Webby, B. D., Nestor, H. \& Stock, C. W. 1999. Revised classification and terminology of Palaeozoic stromatoporoids. Acta Palaeontologica Polonica, 44, 1-70.

Stock, C. W. 1990. Biogeography of the Devonian stromatoporoids. In: Palaeozoic Palaeogeography and Biogeography (eds. W. S. McKerrow \& C. R. Scotese). Geological Society, Memoir, 12, 257-265, London.

Stock, C. W., 1994: Stromatoporoid paleobiogeography of the Eastern Americas Realm during the Lochkovian Age (Early Devonian). In: Sponges in Time and Space: Biology, Chemistry, Paleontology (eds. R. W. m. van Soest, T. M. G. van Kempen \& J.-C. Braekman). Balkema, Rotterdam, 23-27.

Stock, C. W. 1997. Paleobiogeographical range of North American Devonian stromatoporoids: roles of global and regional controls. Boletín de la Real Sociedad Española de Historia Natural (Seccíon Geológica), 92, 281-288.

Webby, B. D. \& Zhen, Y. Y. 1993. Lower Devonian stromatoporoids from the Jesse Limestone of the Limekilns area, New South Wales. Alcheringa, 17, 327-352.

Webby, B. D. \& Zhen, Y. Y. 1997. Silurian and Devonian clathrodictyids and other stromatoporoids from the Broken River region, north Queensland. Alcheringa, 21, 1-56.

Webby, B. D., Stearn, C. W. \& Zhen, Y. Y. 1993. Lower Devonian (Pragian-Emsian) stromatoporoids from Victoria. Proceedings of the Royal Society of Victoria, 105, 113-185.

Yang Jingzhi \& Dong Deyuan 1979. Devonian stromatoporoids from central and eastern parts of Guangxi, China. Palaeontologia sinica, new series $\boldsymbol{B}, \mathbf{1 4}$ [whole number 157], 89 pp.

Manuscrito recibido: 18 de Noviembre de 2004 Manuscrito aceptado: 9 de Diciembre de 2005 